The Effect of Citric Acid and Ascorbic Acid Dips on Storage and Quality Properties of Fresh Cut Kiwifruit Slices

Ömür DÜNDAR ${ }^{1}$, Hatice DEMIRCIOĞLU², Okan ÖZKAYA ${ }^{3}$, Burcu DÜNDAR ${ }^{4}$

${ }_{1,2,3}$ Cukurova University, Agriculture Faculty, Horticulture Department, Sarıcam, Adana, ${ }^{4}$ Cukurova University, Agriculture Faculty, Food Engineering Department, Sarıcam, Adana

${ }^{1}$ https://orcid.org/0000-0002-2388-0333, ${ }^{2}$ https://orcid.org/0000-0003-2469-5030, ${ }^{3}$ https://orcid.org/0000-0002-9448-5576,

${ }^{4}$ https://orcid.org/0000-0002-9919-5711,

$\varangle$ : odundar@cu.edu.tr

\begin{abstract}
In this study, the effect of $1 \%$ ascorbic acid and $1 \%$ citric acid solutions and dionize water (control) dips on storage and quality properties of fresh cut kiwifruit slices was investigated. The fruits were washed, peeled, sliced, and the slices packaged with stretch film after immersion in the solutions. Kiwifruit slices packaged were kept at $4^{\circ} \mathrm{C}$ for 12 days. In kiwifruit samples, physical and chemical changes such as weight loss (\%), fruit flesh firmness (Shore), total soluble solids (\%), titretable acidity (\%), $\mathrm{pH}$ value, fruit flesh color $\left(\mathrm{h}^{\circ}\right)$, vitamin $\mathrm{C}$ (L-Ascorbic acid), total fenolic compounds (mg gallik acid.L-1), antioksidant activity (\%), appearance were determined in each 3 days during shelf life. The highest $h^{\circ}$ angle value was determined in $1 \%$ citric acid treatment. Among the treatments, the highest firmness at the end of storage was determined in $1 \%$ ascorbic acid treatment. Results showed that $1 \%$ citric acid and $1 \%$ ascorbic acid dips had a positive effect on overall quality parameters of kiwifruit slices.
\end{abstract}

\title{
Sitrik ve Askorbik Asit Daldırmalarının Taze Doğranmış Kivi Dilimlerinin Depolanması ve Kalite Özellikleri Üzerine Etkisi
}

\section{ÖZET}

$\mathrm{Bu}$ çalışmada, taze kesilmiş kivi dilimlerinin depolama ve kalite özellikleri üzerine \%1 askorbik asit ve \%1 sitrik asit çözeltileri ve dionize su (kontrol) daldırma uygulamalarının etkisi araştırılmıştır. Meyveler yıkanmış, soyulmuş, dilimlenmiş ve dilimler, çözeltilere daldırıldıktan sonra streç film ile paketlenmiştir. Paketlenen kivi dilimleri 12 gün boyunca $4^{\circ} \mathrm{C}^{\prime}$ de muhafaza edilmiştir. Kivi örneklerinde ağırlık kaybı (\%), meyve eti sertliği (Shore), suda çözünür toplam kuru madde (\%), titre edilebilir asitlik (\%), $\mathrm{pH}$ değeri, meyve et rengi $\left(\mathrm{h}^{\circ}\right), \mathrm{C}$ vitamini (L-Askorbik asit), toplam fenolik bileşikler ( $\mathrm{mg}$ gallik asit.L-1), antioksidan aktivite (\%) ve görünüm gibi fiziksel ve kimyasal özellikler raf ömrü boyunca üç günde bir belirlenmiştir. En yüksek $h^{\circ}$ değeri $\% 1$ sitrik asit uygulamasından, en yüksek sertlik $\% 1$ askorbik asit uygulamasından elde edilmiştir. Sonuçlar, \%1 sitrik asit ve \%1 askorbik asit çözeltilerine daldırma uygulamalarının kivi dilimlerinin genel kalite parametreleri üzerinde olumlu bir etkiye sahip olduğunu göstermiştir.

\section{Research Article}

\section{Article History}

Received

$: 20.01 .2020$

Accepted $\quad: 17.03 .2020$

\section{Keywords}

Kiwifruit

Dipping

Citric acid

Ascorbic acid

Fresh Cut

To Cite : Dundar O, Demircioglu H, Ozkaya O, Dundar B 2020. The Effect of Citric Acid and Ascorbic Acid Dips on Storage and Quality Properties of Fresh Cut Kiwifruit Slices. KSU J. Agric Nat. 23 (4): 807-815. DOI: 10.18016/ksutarimdoga.vi.677688.

\section{INTRODUCTION}

Kiwifruit, bringing higher revenue per unit area, next to a wealth of vitamin and mineral substances to be low-calorie aspect is one of the productions and consumption of fruit species rapidly increasing in

\section{Araştırma Makalesi}

Makale Tarihçesi
Geliş Tarihi $\quad: 20.01 .2020$
Kabul Tarihi

Anahtar Kelimeler

Kivi

Daldırma

Sitrik asit

Askorbik asit

Taze doğranmış recent years (Bostan and Günay, 2014). Consumers in Turkey demand for vegetables and fresh fruits has increased in recent years. The consumers usually judge the quality of fresh-cut fruit of freshness and appearance at the time of purchase (Kader, 2002). 
However, to protect the long-term quality of these products is still a major problem to be overcome. Products during the preparation of fresh-cut products undergo various injuries and bruises scratches. These injuries and bruises cause the softening and discoloration of the tissues, which increases the enzymatic activities, resulting in shortening the shelf life and storage of the products. Applying antioxidant treatments as dipping after peeling or cutting is the most common way to control the browning of freshly cut fruits. Organic acids (citric, lactic, tartaric and acetic acid) have been identified as potent antimicrobial agents due to environmental $\mathrm{pH}$ reduction, membrane permeability and transport impairment, anion accumulation or a reduction in internal cellular pH (Parish et al., 2003). Carboxylic acids (oxalic acid and citric acid) have been also proposed as effective antioxidant agents in freshly cut fruits (Jiang et al., 2004; Son et al., 2001; Pizzocaro et al., 1993).

Less direct antibacterial activities include interference with nutrient transport, cytoplasm membrane damage resulting in leakage, disruption of outer membrane permeability, and influence onmacromolecular synthesis (Beuchat, 1998; Inatsu et al, 2005; Miller et al., 2009). Citric and ascorbic acids are commonly used in fruit and vegetable washing and added in fruit juices (Velazquez et al. 2009). Ascorbic acid is the most commonly used organic acids to prevent enzymatic browning of cut fruit due to the return of the o-quinones produced by the action of PPO enzymes to phenolic substrates. (McEvily et al, 1992). However, ascorbic acid oxidizes to dehydroascorbic acid after a certain period of time, thus allowing O-Quinones to accumulate (Luo and Barbosa-Canovas, 1997; Rojas-Grau et al, 2008; Sapers, 1993). Several studies have been done to reduce these quality losses and thus achieve greater shelf life in freshly cut fruits.

Jang and Moon (2011), investigated the effects of ultrasound and ascorbic acid on polyphenol oxidase and peroxidase activity in freshly cut apples during storage. Combined treatment of ultrasound and ascorbic acid was found to be ineffective in monophenolase, diphenolase and peroxidase, but with inverse and limited inhibitory effect on individual ultrasound or ascorbic acid enzymes. This research has revealed that simultaneous treatment with ultrasonic and ascorbic acid has synergistic inhibitory effects on various enzymes related to enzymatic browning.

Agar et al. (1999) showed that fresh-cut kiwifruit had a shelf-life of 9-12 days if treated with $1 \%$ of $\mathrm{CaCl}_{2}$ or $2 \%$ of calcium lactate, and stored at $0-2 \circ \mathrm{C}$ in an ethylene-free atmosphere of $2-4 \mathrm{kPa}$ of $\mathrm{O}_{2}$ and/or 5$10 \mathrm{kPa}$ of $\mathrm{CO}_{2}$.

Slices containing 8 varieties of nectarine and 13 varieties of peaches have changed shelf life (2-12 days at $8^{\circ} \mathrm{C}$ ). Controlled atmospheres of $0.25 \mathrm{kPa} \mathrm{O} 2$ and 10 $\mathrm{kPa}$ or $20 \mathrm{kPa} \mathrm{CO}_{2}$ extend shelf life from Control (air) to 1-2 days in $10^{\circ} \mathrm{C}$ Elegant Lady or O'Henry peach slices. $1 \%$ calcium lactate $+2 \%$ ascorbic acid dipping after cutting resulted in a limited reduction of texture softening and browning of the cut surface in Carnival peach slices (Gorny et al., 1999).

The quality indices of fresh cut fruits and the effects of processing and storage on the nutrient content were evaluated when compared to all fruits stored during the same time but prepared on the day of sampling. Pineapple, mango, melon, watermelon, strawberry and kiwifruit fresh cut were kept open at $5^{\circ} \mathrm{C}$ for 9 days. The visual appearance after cutting shows that the shelf life for freshly cut kiwifruit is 6 days and for strawberry, pineapple and melon is 9 days. On the other hand, freshly cut mango and watermelon were found to be marketable after 9 days. Loss of vitamin $\mathrm{C}$ was $25 \%$ in melon cubes, $12 \%$ in kiwifruit slices, $10 \%$ in pineapple slices and $5 \%$ in mango, strawberry and watermelon slices, after 6 days. Loss of carotenoid was not observed in kiwifruit slices and melon cubes but loss of carotenoid was 10$15 \%$ mango, strawberry and melon slices and 25\% pineapples after 5 days. There was no significant loss in total phenolics after 6 days in freshly cut fruits. Light exposure encouraged browning in pineapple and decreased vitamin $\mathrm{C}$ content in kiwifruit. Total carotenoid content in mango and watermelon increased, but decreased in melon and kiwifruit in response to exposure to light during storage at $5^{\circ} \mathrm{C}$ up to 9 days. There was no effect of exposure to the phenolic contents. In generally, fresh-cut fruits were clearly impaired before significant nutrient loss occurred (Gil et al., 2006).

Effects of heat treatments on the quality of minimally processed kiwifruit with calcium dipping have investigated. All the fruits were cooled to $4^{\circ} \mathrm{C}$ after immersion in water, $\mathrm{CaCl}_{2}$ solutions (1, 2 and 3\%) for 25 minutes at $45^{\circ} \mathrm{C}$. After 24 hours, the fruits were peeled, sterilized, sliced and packed. 8 days of immersion treatments calcium firmness kiwifruit slices was effective during storage at $4^{\circ} \mathrm{C}$ (Beirão-DaCosta et al., 2008).

Cucumbers (Cucumber sativus L. 'Beith Alpha') were peeled, sliced and then stored at $4^{\circ} \mathrm{C}$ for 7-10 days in modified atmosphere packet (MAP). On the positive result of MAP, cucumber slices were stored in the same solution in calcium lactate $(5 \%)$, calcium lactate $(5 \%)+$ ascorbic acid $(5 \%)$ or only immersed in water. One of the most important factors causing quality losses in sliced wells was weight or water loss, and the best way to prevent it was to register as MAP. MAP has increased the shelf life of sliced cucumber fruits at $4^{\circ} \mathrm{C}$ from 2 days to 5 to 7 days. Softening and quality losses in the slices could be delayed by 
calcium lactate applications. Calcium lactate increased shelf life of sliced cucumber juice, which was limited to 5 days, to MAP days to 9 days. Treatment of MAP together with calcium lactate has resulted in increased shelf life of freshly cut cucumber slices (Ergun and Ergun, 2007).

Softening and gas exchange rates of kiwifruit were measured during two seasons under a range of MAP $\left(0-21 \mathrm{kPaO}_{2}, 0-5 \mathrm{kPa} \mathrm{CO} 2\right)$ at $0-10^{\circ} \mathrm{C}$ to by Hertog et al., 2004. Partial pressures of $\mathrm{CO} 2$ delayed the softening. However, it could not inhibit the gas exchange rate. Lower $\mathrm{O}_{2}$ levels did not completely prevent softening, which suggests that the softening rate was driven by the energy provided by both oxidative and fermenting processes. The correlation between the MAP application and the softening rate/gas exchange rate were explained the $88 \%$ of the effect of MA. Also, shelf-life simulations have shown that lowering $\mathrm{O}_{2}$ during storage $\left(\right.$ at $\left.0^{\circ} \mathrm{C}\right)$ or raising $\mathrm{CO}_{2}$ results with an extended shelf life at temperatures higher than $3^{\circ} \mathrm{C}$ (Hertog et al., 2004).

A nonconventional atmosphere $\left(65 \% \mathrm{~N}_{2} \mathrm{O}, 25 \% \mathrm{Ar}, 5 \%\right.$ $\mathrm{CO}_{2}, 5 \% \mathrm{O}_{2}$ ), combined with a dipping treatment in an aqueous solution of $0.5 \%$ of citric acid, $0.5 \%$ of calcium chloride and $0.5 \%$ of ascorbic acid for $3 \mathrm{~min}$ have maintained the fresh quality of minimally processed apples for 12 days (Rocculi et al., 2004).

The shelf life of fresh cut kiwifruit is principally limited by colour degradation and softening, caused by increased enzymatic activities as a result of injury. MAP, which is nontraditional gas mixtures, has been tested on maintaining some of the physicochemical properties of freshly cut kiwifruit during chilled storage. The kiwifruits were sealed into polypropylene boxes stored in air (control) and in three different modified atmospheres ( $\mathrm{Ar}(90 \%), \mathrm{O}_{2}$ (5\%), $\mathrm{CO}_{2}(5 \%) ; \mathrm{N}_{2}(90 \%), \mathrm{O}_{2}(5 \%), \mathrm{CO}_{2}(5 \%)$ and $\mathrm{N}_{2} \mathrm{O}$ (90\%), $\left.\mathrm{O}_{2}(5 \%), \mathrm{CO}_{2}(5 \%)\right)$. In conclusion, the modified atmosphere containing $90 \%$ of $\mathrm{N}_{2} \mathrm{O}, 5 \%$ of $\mathrm{O}_{2}$ and $5 \%$ of $\mathrm{CO}_{2}$, was the best mixture of gases regarding firmness, color and TSS, lowering respiratory activity. The use of a $\mathrm{N}_{2} \mathrm{O}$ modified atmosphere together with a calcium salt treatment could have contributed to the prolongation high quality properties of freshly cut kiwifruit. The effects of argon were somewhat positive, not for the preservation of color, but only for the preservation of firmness, and for slowing breathing. This protective effect of $\mathrm{N}_{2} \mathrm{O}$ obtained on freshly cut kiwifruit quality can be effective in all climacteric fruits (Rocculi et al., 2005).

In this study, the effects of the ascorbic acid and citric acid dipping on storage and quality characteristics which are weight loss (\%), flesh color $\left(h^{\circ}\right)$, flesh firmness (Shore), $\mathrm{pH}$, titratable acidity (TA, \%), total soluble solids (TSS, \%), vitamin C (L-Ascorbic acid), antioxidant activity (\%) and total phenolic content (mg gallic acid.L-1) of kiwi slices were investigated.

\section{MATERIAL and METHOD}

\section{Material}

The kiwifruit (Actinidia deliciosa cv. 'Hayward') were harvested (7 November, 2016) from Mersin (Çağlarca village), when TSS was $6.5 \%$, and flesh firmness was $81.16 \mathrm{~N}$, in the first week of November. Kiwifruit were selected as uniform size (110-120 g), no visual defect and color and immediately transferred to the postharvest laboratory of Horticulture Department of Cukurova University, Adana-Turkey, within 1 hour in a frigorific truck at $4 \pm 0.5^{\circ} \mathrm{C}$ and $90 \pm 5 \%$ relative humidity.

\section{Method}

Kiwifruits were selected and washed. Then it was peeled and sliced. The applied slices were packaged and are stored for 12 days at $4^{\circ} \mathrm{C}$.

\section{Dipping and general analysis}

All kiwifruit is rinsed in 1\% hypochlorite water for 5 minutes. After rinsing, fruits are stripped and each fruit is divided into four equal parts. Fruit slices were adjusted according to each application and kept for 5 minutes in $1 \%$ ascorbic acid water, $1 \%$ citric acid water and deionize water (control) respectively. Ten slices of kiwifruit were placed on each polypropylene (pp) plate and packaging was done using stretch film. Packaged cleaved kiwifruits are stored for 12 days at $4^{\circ} \mathrm{C}$ and $0,3 ., 6 ., 9$. and 12. day physical and chemical changes such as weight loss (\%), fruit flesh firmness (shore), TSS (\%), TA (\%), pH, fruit flesh color $\left(h^{\circ}\right)$ were determined. The weight loss in weight during storage was calculated by subtracting the final weight from the initial weight of fruits and expressed in per cent. Fruit flesh firmness was calculated by shoremeter. TSS of fruit slices were determined at room temperature by using Refractometer having a range of 0 to $32^{\circ}$ Brix by putting a drop of fruit juice and taking the readings. For TA $5 \mathrm{~mL}$ fruit juice was mixed with $45 \mathrm{~mL}$ distilled water. Mixture was titrated to $\mathrm{pH}$ of 8.1 with $\mathrm{NaOH}(0.1 \mathrm{~N})$. TA was expressed as the percentage of citric acid mg.100 g-1. $\mathrm{pH}$ value was calculated by $\mathrm{pH}$ meter. Fruit flesh color $\left(\mathrm{h}^{\circ}\right)$ was determined by color meter (CR 400, Minolta).

\section{L-Ascorbic acid content}

L-Ascorbic acid (vitamin C) was determined by the spectrophotometric (UV-1800 240V, Shimadzu Japan) method. $5 \mathrm{~mL}$ of fruit juices were kept into a glass cup with $45 \mathrm{~mL}$ of $45 \mathrm{~mL} \% 0.4$ oxalic acid, shaken, and filtered through filter. Then, one $\mathrm{mL}$ of the filtrate is taken into two tubes. $9 \mathrm{~mL} 2.6$ dichlorophenolindophenol solution is added to one of the tubes and $9 \mathrm{~mL}$ of purified water is added to the other tube. Immediate $\mathrm{L}_{2}$ reading is read at $520 \mathrm{~nm}$ 
transmitter. First, the $\mathrm{L}_{1}$ reading is performed. $\mathrm{L}_{1}$ reading; $1 \mathrm{~mL} \quad 0.4 \%$ oxalic acid $+9 \quad \mathrm{~mL} \quad 2.6$ dichlorophenolindophenol solution is put in one tube and $10 \mathrm{~mL}$ pure water is placed in the other tube (Özdemir and Dündar, 2006; Dündar et al., 2014; Equality 1).

$$
\mathrm{L}-\text { ascorbic acid }(m g \text { ascorbic acid } / 100 \mathrm{~mL} \text { juice })=\frac{\text { Curve factor. }\left(\mathrm{L}_{1}-\mathrm{L}_{2}\right) \cdot 100}{5 \mathrm{~mL} \text { juice }}
$$

\section{Total Phenolic Content}

Total phenol was extracted from a $5 \mathrm{~g}$ juice of fruit samples with $5 \mathrm{~mL}$ of $80 \%$ methanol. Then total phenol was determined by the Folin-Ciocalteu method with measurement at $765 \mathrm{~nm}$ absorbance using spectrophotometer (UV-1800 240V, Shimadzu Japan). The results were expressed as $\mathrm{mg}$ of gallic acid equivalents (GAE) per g dry weight (Cemeroğlu, 2018).

\section{Antioxidant Activity}

For Antioxidant activity (\%), one complementary assay was used DPPH. $5 \mathrm{~mL}$ of a kiwi juice sample was added to $5 \mathrm{~mL}$ of $80 \%$ methanol solution and vortexed sufficiently and then centrifuged (Rotina 38R, Hettich, Zentrifugen, Germany) for 20 minutes at $4000 \mathrm{rpm}$ at $4^{\circ} \mathrm{C} .2460 \mu \mathrm{L}$ 1,1-diphenyl-2picrilhydrazil (DPPH; 0.025g.L-1 in $80 \%$ methanol) was added to $100 \mu \mathrm{L}$ of fruit juice sample from the centrifuged sample. The absorbance of the samples was measured at $515 \mathrm{~nm}$ in spectrophotometer (UV1800 240V, Shimadzu Japan) at 0, 5, 20 minutes against $80 \%$ methanol without wasting time and the 20 -minute data was used. Antioxidant activity was expressed as \% inhibition of DPPH using the following equation (Klimczak et al., 2007; Equality 2).

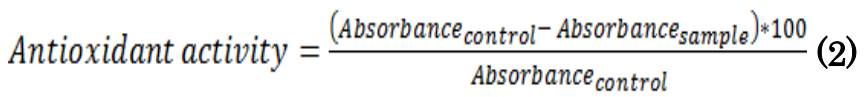

\section{General Appearence and Taste}

The changes in appearance and taste of the fruit during the storage period were investigated. The fruit slices were tasted by 5 people during the periodical analysis days and evaluated according to the scale (very bad, bad, medium, good and very good). Views of the slices were periodically photographed.

\section{Statistical Analysis}

The experiment is based on the experimental pattern of random parcels in factorial order. The experiment Control, 1\% ascorbic acid and $1 \%$ citric acid treatments were established as 10 slices of fruit in each replicate and all data are means of 3 replicates. Each treatment was performed according to the JMP package program and $\mathrm{LSD}=0.05$.

\section{RESULTS and DISCUSSIONS}

The weight loss of kiwifruits was given in Table 1 . Maximum weight loss determined was in ascorbic acid group, followed by citric acid and control treatments during storage. However, the difference between the weight losses of kiwi fruits treated with different solutions was not statistically significant during storage. Weight losses of all kiwi fruits increased value during the storage period. Since the fruit slices were kept wrapped in stretch film after treatment, the weight losses of different treatments were close to each other. Rocculi et al. (2005) determined a similar tendency for weight loss values of minimally processed kiwifruit during storage. Also, it was reported that the same property of kiwifruit was reached an approximate value on the 12 th day of storage under air or $5 \% \quad \mathrm{CO}_{2}, \quad 5 \% \mathrm{O}_{2}, \quad 90 \% \quad \mathrm{~N}_{2}$ atmosphere.

Table 1. The effect of Citric acid and Ascorbic acid dips on weight loss (\%) of kiwifruits slices

Clizelge 1. Sitrik asit ve askorbik asit daldırma uygulamalarının kivi dilimlerinin ağırlık kaybı (\%) değerleri üzerine etkisi

\begin{tabular}{lccccc}
\hline & \multicolumn{4}{c}{ Storage Time (day) (Muhafaza Süresi (gün)) } & \\
\cline { 2 - 5 } Treatment (Uygulama) & $\mathbf{3}$ & $\mathbf{6}$ & $\mathbf{9}$ & $\mathbf{1 2}$ & Mean (Ortalama) \\
\hline Control (Kontrol) & 0.16 & 0.31 & 0.47 & 1.06 & $0.50 \mathrm{c}$ \\
\%1 Ascorbic acid & 0.45 & 0.84 & 1.11 & 1.61 & $1.00 \mathrm{a}$ \\
\%1 Citric acid & 0.33 & 0.62 & 0.78 & 1.20 & $0.74 \mathrm{~b}$ \\
\hline Mean (Ortalama) & $0.31 \mathrm{c}$ & $0.59 \mathrm{~b}$ & $0.79 \mathrm{~b}$ & $1.29 \mathrm{a}$ & \\
\hline
\end{tabular}

$\operatorname{LSD}_{(0.05)}$ Treatment:0.15 LSD $(0.05)$ Storage Time: 0.17 LSD $(0.05)$ TreatmentXStorage Time: N.S.****NS: Nonsignificant

During storage, $\mathrm{h}^{\circ}$ angle values in kiwifruit slices were found close to each other (Table 2). 1\% Ascorbic acid and $1 \%$ Citric acid treatments had higher values of $h^{\circ}$ angle than control. The $h^{\circ}$ values of kiwifruits showed significant increase during storage until the
9. day. Beirão-Da-Costa et al. (2006) found that the combination of heat and time did not affect the color of the kiwifruit slices and there was no enzymatic reaction. The change in weight loss and color of kiwifruit indicated the involvement of another 
anaerobic process that affected the rates of both weight loss and color change (Hertog et al., 2004).

The effects of storage on fruit flesh firmness was found statistically important $(p<0.05)$ (Table 3.). At the end of the storage, the highest average value was determined in the treatment of $1 \%$ ascorbic acid. Beirão-Da-Costa et al. (2006) and Rocculi et al. (2005), also found that firmness decreased during kiwifruit slices during storage. It was indicated that, the rates of softening could be related to the combined effect of fermentation and respiration in apple and kiwifruit by Rocculi et al. (2005).

The values of TSS content significantly decreased during storage (Table 4). The highest amount of TSS content was in the control, followed by $1 \%$ ascorbic acid and $1 \%$ citric acid, respectively. In addition, it was determined that there is a significant effect of the treatment on the amount of TSS content. The TSS value of control group was found higher than the kiwifruits treated with ascorbic or citric acid.

Table 2. The effect of Citric acid and Ascorbic acid dips on $\mathrm{h}^{\circ}$ value of kiwifruits slices

Cizelge 2. Sitrik asit ve askorbik asit daldırma uygulamalarının kivi dilimlerinin $h^{\circ}$ değerleri üzerine etkisi

\begin{tabular}{lcccccc} 
& \multicolumn{7}{c}{ Storage Time (day) (Muhafaza Süresi (gün)) } & \\
Treatment (Uygulama) & 0 & 3 & 6 & 9 & 12 & Mean(Ortalama) \\
\cline { 2 - 6 } Control (Kontrol) & 118.35 & 120.37 & 122.94 & 125.09 & 125.74 & 122.50 \\
\%1 Ascorbic acid & 118.35 & 120.63 & 122.30 & 127.95 & 125.96 & 123.04 \\
\%1 Citric acid & 118.35 & 121.57 & 124.51 & 126.67 & 125.40 & 123.30 \\
\hline Mean (Ortalama) & $118.35 \mathrm{~d}$ & $120.86 \mathrm{c}$ & $123.25 \mathrm{~b}$ & $126.57 \mathrm{a}$ & $125.70 \mathrm{a}$ & \\
\hline
\end{tabular}

LSD $_{(0.05)}$ Treatment:N.S. LSD $(0.05)$ Storage Time: 1.58 LSD $(0.05)$ TreatmentXStorage Time: N.S.. $\left(L S D_{(0,05)}\right.$

Table 3. The effect of Citric acid and Ascorbic acid dips on fruit flesh firmness (shore) of kiwifruit slices

Cizelge 3. Sitrik asit ve askorbik asit daldırma uygulamalarının kivi dilimlerinin meyve eti sertliği (shore) üzerine etkisi

\begin{tabular}{lcccccc}
\hline & \multicolumn{5}{c}{ Storage Time (day) (Muhafaza Süresi (gün)) } & \\
\cline { 2 - 6 } Treatment (Uygulama) & 0 & 3 & 6 & 9 & 12 & Mean(Ortalama) \\
\hline Control & 29.08 & 4.51 & 2.22 & 1.51 & 1.06 & 7.68 \\
\%1 Ascorbic acid & 29.08 & 5.63 & 2.77 & 1.52 & 1.46 & 8.09 \\
\%1 Citric acid & 29.08 & 5.64 & 2.46 & 1.52 & 1.13 & 7.97 \\
\hline Mean (Ortalama) & $29.08 \mathrm{a}$ & $5.26 \mathrm{~b}$ & $2.48 \mathrm{c}$ & $1.52 \mathrm{~cd}$ & $1.21 \mathrm{~d}$ & \\
\hline
\end{tabular}

LSD $_{(0.05)}$ Treatment: N.S. LSD $(0.05)$ Storage Time: 1.12 LSD $_{(0.05)}$ TreatmentXStorage Time: N.S. $\left(L S D_{(0,05)}\right.$.

Table 4. The effect of Citric acid and Ascorbic acid dips on total soluble solids content (\%) of kiwifruits slices Cizelge 4. Sitrik asit ve askorbik asit daldırma uygulamalarının kivi dilimlerinin toplam suda çözünür kuru madde (\%) içeriği üzerine etkisi

\begin{tabular}{lcccccc}
\hline & \multicolumn{7}{c}{ Storage Time (day) } & (Muhafaza Süresi (gün)) & \\
\cline { 2 - 6 } Treatment (Uygulama) & 0 & 3 & 6 & 9 & 12 & Mean (Ortalama) \\
\hline Control (Kontrol) & 15.13 & 14.00 & 13.93 & 13.67 & 13.80 & $14.11 \mathrm{a}$ \\
\%1 Ascorbic acid (\%1 Askorbik asit) & 15.13 & 13.80 & 13.53 & 13.67 & 14.00 & $14.03 \mathrm{a}$ \\
\%1 Citric acid (\%1 Sitrik asit) & 15.13 & 13.27 & 13.33 & 13.00 & 13.40 & $13.63 \mathrm{~b}$ \\
\hline Mean (Ortalama) & $15.13 \mathrm{a}$ & $13.69 \mathrm{bc}$ & $13.60 \mathrm{bc}$ & $13.44 \mathrm{c}$ & $13.73 \mathrm{~b}$ &
\end{tabular}

LSD $_{(0.05)}$ Treatment: 0.84 LSD $_{(0.05)}$ Storage Time: 1.08 LSD $_{(0.05)}$ TreatmentXStorage Time: N.S. $\left(L S D_{(0,05)}\right.$

The $\mathrm{pH}$ values reduced in all three treatments during storage (Table 5). In the control group, $\mathrm{pH}$ values were found to be higher than other treatments. The effect of citric acid dip was higher than the effect of citric acid on $\mathrm{pH}$ of kiwifruit. The effect of treatment, storage time and combination of them on $\mathrm{pH}$ were statistically significant at $5 \%$ significance level.

The level of TA content in terms of citric acid which is major acid of kiwifruit was given in Table 6. TA content in each of the three treatments was decreased with the increasing storage time. This decrease can be related with the degradation of organic acids. Gil et al. (2006) also found that TSS content, TA content and the $\mathrm{pH}$ value decreased during storage in kiwifruit slices. In this study, TSS content, TA content and $\mathrm{pH}$ value in kiwifruit slices were decreased.

The change in taste and appearance of the kiwifruit during the storage period were investigated. In general, it was determined that the tastes were close to each other and the slice stiffness in the mouth was different (evaluation data were not given). Kiwifruit slices dipped in citric acid and ascorbic acid were found to be hard during storage. The appearance of slices during storage was shown in Figure 1. It was observed that the color was opened in the kiwi slices during the storage period. 
Table 5. The effect of Citric acid and Ascorbic acid dips on $\mathrm{pH}$ of kiwifruits slices

Cizelge 5. Sitrik asit ve askorbik asit daldırma uygulamalarının kivi dilimlerinin pH değerleri üzerine etkisi

\begin{tabular}{lcccccc} 
& \multicolumn{4}{c}{ Storage Time (day) (Muhafaza Süresi (gün)) } & \multicolumn{2}{c}{ Mean (Ortalama) } \\
\cline { 2 - 6 } Treatment (Uygulama) & 0 & 3 & 6 & 9 & 42 & $4.63 \mathrm{a}$ \\
Control (Kontrol) & $4.80 \mathrm{a}$ & $4.67 \mathrm{~b}$ & $4.61 \mathrm{~cd}$ & $4.53 \mathrm{f}$ & $4.54 \mathrm{ef}$ & $4.59 \mathrm{~b}$ \\
\%1 Ascorbic acid & $4.80 \mathrm{a}$ & $4.63 \mathrm{bc}$ & $4.59 \mathrm{cde}$ & $4.55 \mathrm{ef}$ & $4.40 \mathrm{~g}$ & $4.54 \mathrm{c}$ \\
\%1 Citric acid & $4.80 \mathrm{a}$ & $4.58 \mathrm{cde}$ & $4.58 \mathrm{def}$ & $4.42 \mathrm{~g}$ & $4.31 \mathrm{~h}$ & $4.42 \mathrm{e}$ \\
\hline Mean (Ortalama) & $4.80 \mathrm{a}$ & $4.63 \mathrm{~b}$ & $4.59 \mathrm{c}$ & $4.50 \mathrm{~d}$ &
\end{tabular}

$\operatorname{LSD}_{(0.05)}$ Treatment: $0.2 \operatorname{LSD}_{(0.05)}$ Storage Time: 0.3 LSD $(0.05)$ Treatment XStorage Time: 0.5. $\left(L S D_{(0,05)}\right.$

Table 6. The effect of Citric acid and Ascorbic acid dips on titratable acidity (citric acid mg/100 g) content of kiwifruits slices

Cizelge 6. Sitrik asit ve askorbik asit daldırma uygulamalarının kivi dilimlerinin titre edilebilir asit (mg sitrik asit $100 \mathrm{~g}^{-1}$ ) içeriği üzerine etkisi

\begin{tabular}{lcccccc}
\hline & \multicolumn{4}{c}{ Storage Time (day) (Muhafaza Süresi (gün)) } & Mean (Ortalama) \\
\cline { 2 - 5 } Treatment (Uygulama) & 0 & 3 & 6 & 9 & 12 & 1.32 \\
Control (Kontrol) & 1.82 & 1.48 & 1.36 & 1.40 & 1.42 & 1.47 \\
\%1 Ascorbic acid & 1.82 & 1.43 & 1.33 & 1.31 & 1.41 & 1.47 \\
\%1 Citric acid & 1.82 & 1.41 & 1.34 & $1.36 \mathrm{c}$ & $1.39 \mathrm{bc}$ \\
\hline Mean (Ortalama) & $1.82 \mathrm{a}$ & $1.44 \mathrm{~b}$ & $1.34 \mathrm{c}$ & 1.35 \\
\hline
\end{tabular}

LSD $_{(0.05)}$ Treatment: N.S. LSD(0.05) Storage Time: 0.07 LSD(0.05) TreatmentXStorage Time: N.S. (LSD(0,05) Uygulama: Ö.D..

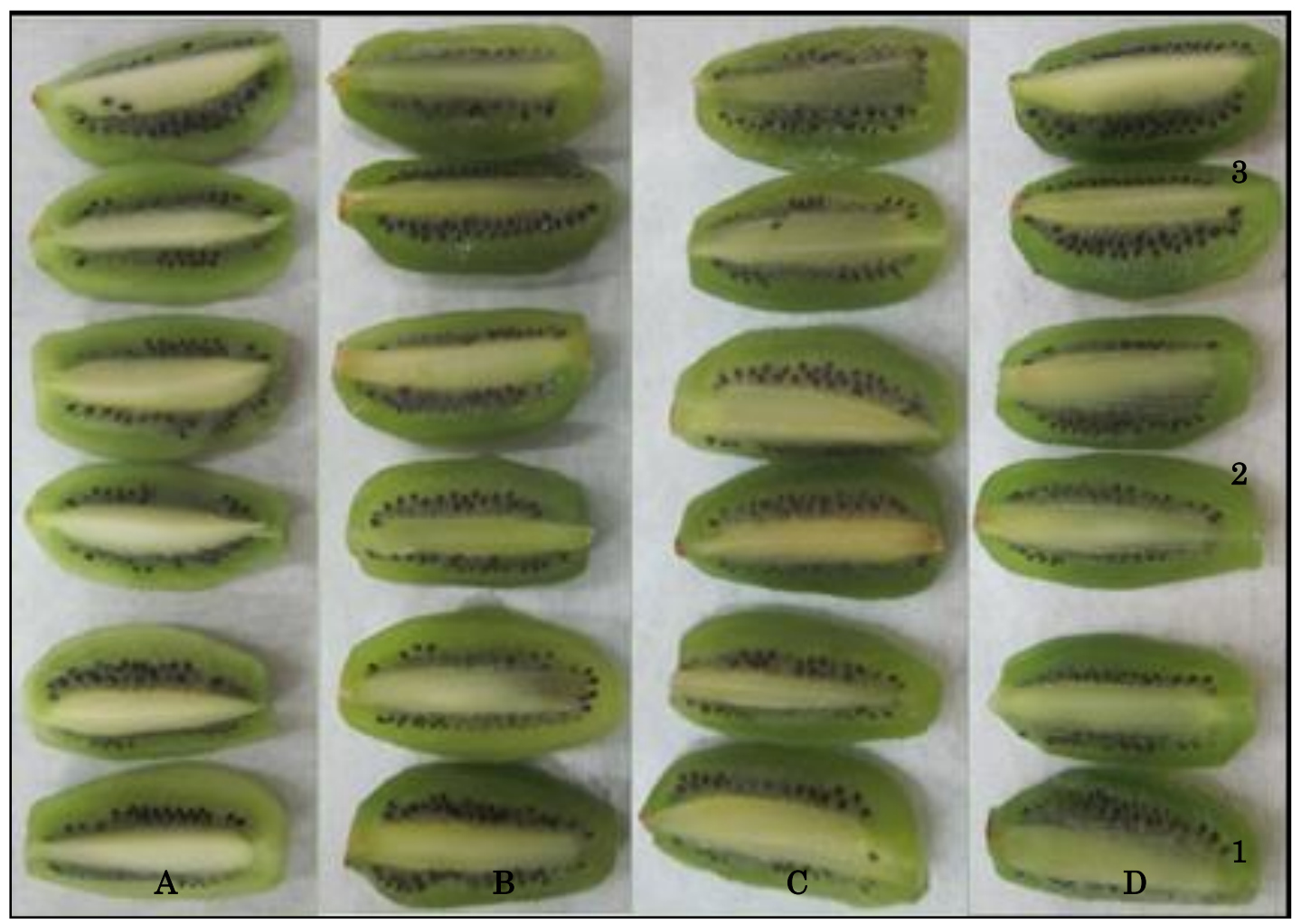

Figure 1. Picture of Ascorbic acid and Citric acid dips during storage of kiwifruits slices; A) 0 day, B) after 3 days storage, C) after 6 days storage, D) after 9 days storage, E) after 12 days storage; 1) control, 2) 1\% ascorbic acid, 3) 1\% citric acid-immersed kiwi slices.

Şekil 1. Muhafaza süresi boyunca sitrik asit ve askorbik asit daldırma uygulanan kivilere ait görseller; A) 0. gün, B) 3. gün, C) 6.gün, D) 9.gün, E) 12.gün; 1) kontrol, 2) 1\% askorbik asit, 3) 1\% sitrik asit.

The effect of storage time and treatment were found to be statistically significant at $5 \%$ level (Table 7 ) on vitamin $\mathrm{C}$ level. One of the features that distinguishes kiwifruit from other fruit and increases its importance for healthy nutrition is the high amount of vitamin C. Although the ascorbic acid levels of kiwifruits were close to each other at the 
beginning of storage, it was observed that the kiwifruit slices treated with ascorbic acid had the highest ascorbic acid level at the end. The kiwifruits were treated with the mentioned organic acids maintained their initial ascorbic acid levels better than the control group until the 9. day of storage. Gil et al. (2006) also showed that vitamin C (L-ascorbic acid) of the kiwifruit slices decreased during storage.

Table 7. The effect of Citric acid and Ascorbic acid dips on vitamin C content (L-ascorbic acid mg.100 g-1) of kiwifruits slices

Cizelge 7. Sitrik asit ve askorbik asit daldırma uygulamalarının kivi dilimlerinin $C$ vitamini içeriği (mg Laskorbik asit.100 g-1) üzerine etkisi

\begin{tabular}{lcccccc}
\hline & \multicolumn{4}{c}{ Storage Time (day) (Muhafaza Süresi (gün)) } & \\
\cline { 2 - 5 } Treatment (Uygulama) & 0 & 3 & 6 & 9 & 12 & Mean (Ortalama) \\
\hline Control (Kontrol) & 35.90 & 35.07 & 34.90 & 34.00 & 33.75 & $34.72 \mathrm{~b}$ \\
\%1 Ascorbic acid & 35.90 & 35.40 & 35.35 & 35.85 & 34.15 & $35.33 \mathrm{a}$ \\
\%1 Citric acid & 35.90 & 35.50 & 35.25 & 34.95 & 33.57 & $35.03 \mathrm{ab}$ \\
\hline Mean (Ortalama) & $35.90 \mathrm{a}$ & $35.32 \mathrm{ab}$ & $35.17 \mathrm{~b}$ & $34.93 \mathrm{~b}$ & $33.82 \mathrm{c}$ \\
\hline
\end{tabular}

$\operatorname{LSD}_{(0.05)}$ Treatment:0.46 LSD $(0.05)$ Storage Time:0.60 LSD(0.05) Treatment XStorage Time: N.S. (LSD(0,05) Uygulama:0,46

In this study, the total phenolic contents of fruits in each treatment and control decreased during 9 days. The highest value (232 mg GAE.L ${ }^{-1}$ ) at the end of storage was determined in $1 \%$ ascorbic acid treatment (Table 8). These values were followed by control and $1 \%$ citric acid treatments, respectively. Statistically, there was no difference between treatments at the end of storage. However, treatments were affected the total phenolic content significantly during the first 6 days of storage $(p<0.05)$. Gil et al. (2006) found an increase in phenolic content on the 9. day of kiwifruit slices during storage.

Table 8. The effect of Citric acid and Ascorbic acid dips on total fenolic content (mg GAE.L-1) of kiwifruits slices Çizelge 8. Sitrik asit ve askorbik asit daldırma uygulamalarının kivi dilimlerinin toplam fenolik madde içeriği (mg GAE.L-1) üzerine etkisi

\begin{tabular}{lcccccc}
\hline & \multicolumn{5}{c}{ Storage Time (day) (Muhafaza Süresi (gün)) } \\
\cline { 2 - 6 } Treatment (Uygulama) & 0 & 3 & 6 & 9 & 12 & Mean (Ortalama) \\
\hline Control (Kontrol) & $414.58 \mathrm{ab}$ & $335.03 \mathrm{bc}$ & $399.58 \mathrm{ab}$ & $219.42 \mathrm{~d}$ & $218.52 \mathrm{~d}$ & 317.42 \\
\%1 Ascorbic acid (\%1 Askorbik asit) & $414.58 \mathrm{ab}$ & $462.76 \mathrm{a}$ & $271.85 \mathrm{~cd}$ & $223.21 \mathrm{~d}$ & $232.00 \mathrm{~d}$ & 320.88 \\
\%1 Citric acid (\%1 Sitrik asit) & $414.58 \mathrm{ab}$ & $398.82 \mathrm{ab}$ & $205.64 \mathrm{~d}$ & $217.76 \mathrm{~d}$ & $193.21 \mathrm{~d}$ & 286.00 \\
\hline Mean(Ortalama) & $414.58 \mathrm{a}$ & $398.87 \mathrm{a}$ & $292.35 \mathrm{~b}$ & $220.13 \mathrm{c}$ & $214.58 \mathrm{c}$ & \\
\hline
\end{tabular}

$\operatorname{LSD}_{(0.05)}$ Treatment: N.S. LSD $(0.05)$ Storage Time: $47.62 \operatorname{LSD}_{(0.05)}$ TreatmentXStorage Time: 82.49. (LSD(0,05)

Antioxidants are a group of compounds that help protect many diseases (heart, blood vessel, cancer, alzheimer, cataract, etc.) by binding active radicals. The effect of treatment and storage time on antioxidant activity was found statistically significant at the level of $5 \%$ (Table 9). The antioxidant activity increased with during storage. The highest increase was determined in kiwifruit treated with $1 \%$ citric acid, while the lowest was determined in control. The obtained results showed that citric acid dipping was the most appropriate treatment to improve the antioxidant activity in kiwifruit. Park et al. (2014) also found similar results to this study and indicated that antioxidant activity of kiwifruit increased during storage.

Table 9. The effect of Citric acid and Ascorbic acid dips on antioxidant activity (\%) of kiwifruits slices Cizelge 9. Sitrik asit ve askorbik asit daldırma uygulamalarının kivi dilimlerinin antioksidan aktivite değerleri (\%) üzerine etkisi

\begin{tabular}{lcccccc}
\hline & \multicolumn{4}{c}{ Storage Time (day) (Muhafaza Süresi (gün)) } & Mean \\
\cline { 2 - 6 } Treatment (Uygulama) & 0 & 3 & 6 & 9 & 12 & (Ortalama) \\
\hline Control (Kontrol) & 81.21 & 81.85 & 88.22 & 89.33 & 89.60 & $86.04 \mathrm{~b}$ \\
\%1 Ascorbic acid(\%1 Askorbik asit) & 81.21 & 83.70 & 88.91 & 89.60 & 91.03 & $86.89 \mathrm{~b}$ \\
\%1 Citric acid(\%1 Sitrik asit) & 81.21 & 88.38 & 90.07 & 90.82 & 91.99 & $88.49 \mathrm{a}$ \\
\hline Mean (Ortalama) & $81.21 \mathrm{~d}$ & $84.64 \mathrm{c}$ & $89.07 \mathrm{~b}$ & $89.92 \mathrm{ab}$ & $90.87 \mathrm{a}$ \\
\hline
\end{tabular}

$\operatorname{LSD}_{(0.05)}$ Treatment: $1.28 \operatorname{LSD}_{(0.05)}$ Storage Time: $1.65 \operatorname{LSD}_{(0.05)}$ TreatmentXStorage Time: N.S. (LSD $(0,05) U_{\text {ygulama: } 1,28}$ 


\section{CONCLUSION}

In this study, it was determined that the ascorbic acid and citric acid immersion processes were positively affected on kiwifruit slices of Hayward kiwifruit variety. The minimum weight loss was obtained in the control group. The highest $h^{\circ}$ angle value was determined in 1\% citric acid treatment. Among the treatments, the highest firmness at the end of storage was determined in 1\% ascorbic acid treatment. While TSS was the highest in the control group, it was determined that other treatments were close to each other. While the $\mathrm{pH}$ value of kiwifruit treated with $1 \%$ citric acid was minimum, the amount of TA was close to each other. $1 \%$ ascorbic and citric acid treatments were found to be better in appearance and taste. Vitamin $\mathrm{C}$ content was higher in 1\% ascorbic acid than other treatments at the end of storage. The maximum total phenolic content was found in fruit treated with $1 \%$ ascorbic acid during storage. The highest value of antioxidant activity was determined in $1 \%$ citric acid treatment. As a result, it was found that kiwifruit slices with $1 \%$ ascorbic acid and citric acid $\operatorname{dip}$ at $4^{\circ} \mathrm{C}$ after 12 days of storage had a positive effect on the preservation and quality properties.

\section{Author Contributions}

Project Administration, Supervision, O.D.; Formal Analysis, Resources, Writing, H.D., B.D.; Original Draft, Review, Editing, O.D., O.O.

\section{Conflicts of Interest}

The authors declare no conflict of interest.

\section{REFERENCES}

Agar IT, Massantini, B Hess-Pierce B, Kader AA 1999. Postharvest $\mathrm{CO}_{2}$ and Ethylene Production and Quality Maintenance of Fresh-Cut Kiwifruit Slices. J. Food Sci., 64: 433-440.

Beirão-Da-Costa S, Steiner A, Correia L, Empis J, Molda o-Martins M 2006. Effects of Maturity Stage and Mild Heat Treatments on Quality of Minimally Processed Kiwifruit. J Food Eng, 76: 616-625.

Beirão-Da-Costa S, Cardoso A, Martins LL, Empis J, Moldão-Martins M 2008. The Effect of Calcium Dips Combined with Mild Heating of Whole Kiwifruit for Fruit Slices Quality Maintenance. Food Chem, 108: 191-197.

Beuchat LR 1998. Surface Decontamination of Fruits and Vegetables Eaten Raw: A Review. Food Safety Unit, World Health Organisation. WHO/FSF/FOS/98, 2: 42.

Bostan SZ, Günay K 2014. 'Hayward' (Actinidia Deliciosa Planch) Kivi Çeşidinin Meyve Kalitesi Üzerine Rakım ve Yöneyin Etkisi. Akademik Ziraat Dergisi, 3 (1):13-22.
Cemeroğlu BS 2018. Gıda Analizleri. 4. Baskı, 480 sy, Dündar Ö, İpek U, Özkaya O, Valizadeh A, Demircioğlu H, Kükürt E 2014. Farklı Yetiştirme Koşullarının Domateslerin Muhafazası Üzerine Etkileri. 10. Sebze Tarımı Sempozyumu, Tekirdağ. 466-472.

Ergun M, Ergun N 2007. Dilimlenmiş Hıyarın Raf Ömrünün Modifiye Atmosfer Paketlemesi ve Kalsiyum Laktat Uygulaması ile Uzatılması. KSU J of Sc and Eng, 10 (2): 94-99.

Gil MI, Aguayo E, Kader AA 2006. Quality Hanges and Nutrient Retention in Fresh-Cut Versus Whole Fruits During Storage. J Agric Food Chem 54: 4284-4296.

Gorny JR, Hess-Pierce B, Kader AA 1999. Quality Changes in Fresh-cut Peach and Nectarine Slices as Affected by Cultivar, Storage Atmosphere and Chemical reatments. J of Food Sci, 64 (3):429-432.

Hertog MLATM, Nicholson E, Jeffery PB 2004. The Effect of Modified Atmospheres on the Rate of Firmness Change of 'Hayward' Kiwifruit. Postharvest Bio and Tech, 31:251-261.

Inatsu Y, Bari L, Kawasaki S, Isshiki K, Kawamoto S 2005. Efficacy of Acidified Sodium Chlorite Treatments in Reducing Escherichia Coli O157:H7 on Chinese cabbage. J of Food Protec, 68 (2):251255.

Jang JH, Moon KD 2011. Inhibition of Polyphenol Oxidase and Peroxidase Activities on Fresh-Cut Apple by Simultaneous Treatment of Ultrasound and Ascorbic Acid. Food Chem, 124: 444-449.

Jiang Y, Pen L, Li J 2004. Use of citric acid for shelf life and quality maintenance of fresh-cut Chinese water chestnut. J of Food Eng, 63: 325-328.

Kader AA 2002. Quality Parameters of Fresh-Cut Fruit and Vegetable Products. In O. Lamikanra (Ed.), Fresh-Cut Fruits and Vegetables. Science, Technology and Market (pp. 11-28), Boca Raton: CRC Press.

Klimczak I, Malecka M, Szlachta M, GliszczyńskaŚwiglo A 2007. Effect of Storage on the Content of Polyphenols, Vitamin $\mathrm{C}$ and the Antioxidant Activity of Orange Juices. J of Food Composition and Analysis, 20: 313-322.

Luo Y, Barbosa-Canovas, GV 1997. Enzymatic browning and its inhibition in new apple cultivars slices using 4-hexylresorcinol in combination with ascorbic acid. Food Sci and Tech Inter, 3: 195-201.

McEvily AJ, Iyengar R, Otwell WS 1992. Inhibition of Enzymatic Browning in Foods and Beverages. Critical Reviews in Food Sci and Nutrition, 32:253273.

Miller FA, Ramos B, Gil MM, Brandão TRS, Teixeira P, Silva CLM 2009. Influence of pH, Type of Acid and Recovery Media on the Thermal Inactivation of Listeria Innocua. Int J of Food Microbiology, 133 (1-2): 121-128. 
Özdemir EA, Dündar Ö, 2006. The Effects of Fungicide and Hot Water Treatments on the Internal Quality Parameters of Valencia Oranges. Asian Journal of Plant Sciences 5 (1):142-146.

Parish ME, Beuchat LR, Suslow TV, Harris LJ, Garrett EH, Farber JN 2003. Methods to reduce/eliminate pathogens from fresh and freshcut produce. Comprehensive Reviews in Food Science and Food Safety, 2:161-173.

Park YS, Im MH, Choi JH, Lee HC, Ham KS, Kang SG, Park YK, Suhaj M, Namiesnik J, Gorinstein S 2014. Effect of Long-Term Cold Storage on Physicochemical Attributes and Bioactive Components of Kiwi Fruit Cultivars. CyTA-J of Food, 12 (4):360-368,

Pizzocaro F, Torregiani D, Gilardi G 1993. Inhibition of Apple Polyphenoloxidase (PPO) By Ascorbic Acid, Citric Acid and Sodium Chloride. J of Food Process and Preserv, 17: 21-30.

Rocculi P, Romani S, Rosa MD 2005. Effect of MAP with argon and nitrous oxide on quality maintenance of minimally processed kiwifruit.
Postharvest Bio and Tech, 35: 319-328.

Rocculi P, Romani S, Dalla Rosa M 2004. Evaluation of Physicochemical Parameters of Minimally Processed Apples Packed in Non-Conventional Modified Atmosphere. Food Res. Int., 37: 329-335.

Rojas-Grau MA, Soliva-Fortuny R, Martı'n-Belloso O 2008. Effect of Natural Antibrowning Agents on Color and Related Enzymes in Fresh-Cut Fuji Apples as an Alternative to the Use of Ascorbic Acid. J of Food Sci, 73: 267-272.

Sapers GM 1993. Browning of Foods: Control by Sulfates, Antioxidants, and Other Means. Food Tech, 47: 75-84.

Son S, Moon K, Lee C 2001. Inhibitory Effects of Various Antibrowning Agents on Apple Slices. Food Chem, 73: 23-30.

Velazquez LD, Barbini NB, Escudero M, Estrada C, de Guzman AMS 2009. Evaluation of chlorine, benzalkonium chloride and lactic acid as sanitizers for reducing Escherichia coli $\mathrm{O} 157: \mathrm{H} 7$ and Yersinia enterocolitica on fresh vegetables. Food Control, 20 (3): 262-268. 